\title{
Present day relief-shaping systems acting on the southern slope of the Făgăraş Mountains (Romania)
}

\author{
Alexandru Nedelea and Laura Comanescu* \\ Faculty of Geography, Geomorphology-Pedology Department, Bucharest University, 010041, \\ No. 1, N. Balcescu Avenue, Bucharest, Romania. \\ ${ }^{*}$ Corresponding author.e-mail: lauracomanescu@yahoo.com
}

The present topography of the Făgăraş Mountains is a snapshot of the long-term evolution that brought about significant alterations of the landscape, and especially of the relief, which has acquired different features depending on the intensity of the relationship between the exogenous and endogenous agents. At present, relief shaping in the study area is controlled by the orographic and climatic features. However, the climate of the high and middle-height mountains is the main cause that determines the mechanism, the intensity and the spatial distribution of the shaping processes. The considerable height of the Făgăraş Mountains, which exceeds $2500 \mathrm{~m}$ altitude is responsible for the vertical zonation of climate and vegetation which implicitly induce the setting of the systems of relief modelling, too.

\section{Introduction}

The Făgăraş Mountains are located in the centraleastern part of the Southern Carpathians, a group of the Romanian Carpathians (figure 1). The central part of the massif crosses the parallel of $45^{\circ} 40^{\prime}$ northern latitude and the meridian of $24^{\circ} 30^{\prime}$ eastern longitude. It unfolds between the Olt Valley in the west and the Tămaşu saddle in the east, at an approximately $70 \mathrm{~km}$ length and it dominates the neighbouring regions by differences in levels of 400-1000 m, along some neat tectonical contacts. The Făgăraş Mountains impose by a narrow ridge, delimitated by abrupt slopes (the higher Carpathian alpine ridge), corresponding to great heights, as the six pyramidal peaks display heights of over $2500 \mathrm{~m}$ (Moldoveanu with $2544 \mathrm{~m}$, Negoiu with 2535 m, Viştea Mare with 2547 m, Călțun with 2522 m, Vânătoarea lui Buteanu with $2507 \mathrm{~m}$, Dara with $2500 \mathrm{~m}$ ) and other 33 peaks with peaks that maintain a height above $2400 \mathrm{~m}$. From the main ridge, which is not fragmented by any transversal valley, secondary ridges and peaks (on which erosion surfaces appear) detach, unfolded to the north (shorter and sharper, falling rapidly into steps) and to the south (long, with more extended steps), resulting in an asymmetric profile.

The predominant rocks are strong metamorphosed crystalline schists which give the relief its massive size; in the western part, there also appear patches of crystallized chalks and dolomites. Tectonic movements from the end of Pliocene and from the Quaternary uplifted these mountains with almost $1000 \mathrm{~m}$, bringing them to altitudes which are superior to the heights of permanent snows, a situation which favoured the extension of glaciers. The glacial relief is specific and it is represented by complex and suspended cirques, glacial valleys with steps and moraines, erratic blocks and karlings microdepressions with lakes. The complexity of the relief is completed by the relief resulting from periglacial processes, being remarked crags, towers,

Keywords. Cryonival processes; Făgăraş Mountains; gelivation processes; nival processes; Romania; torrential processes; geomorphology; natural hazards; physical geography. 


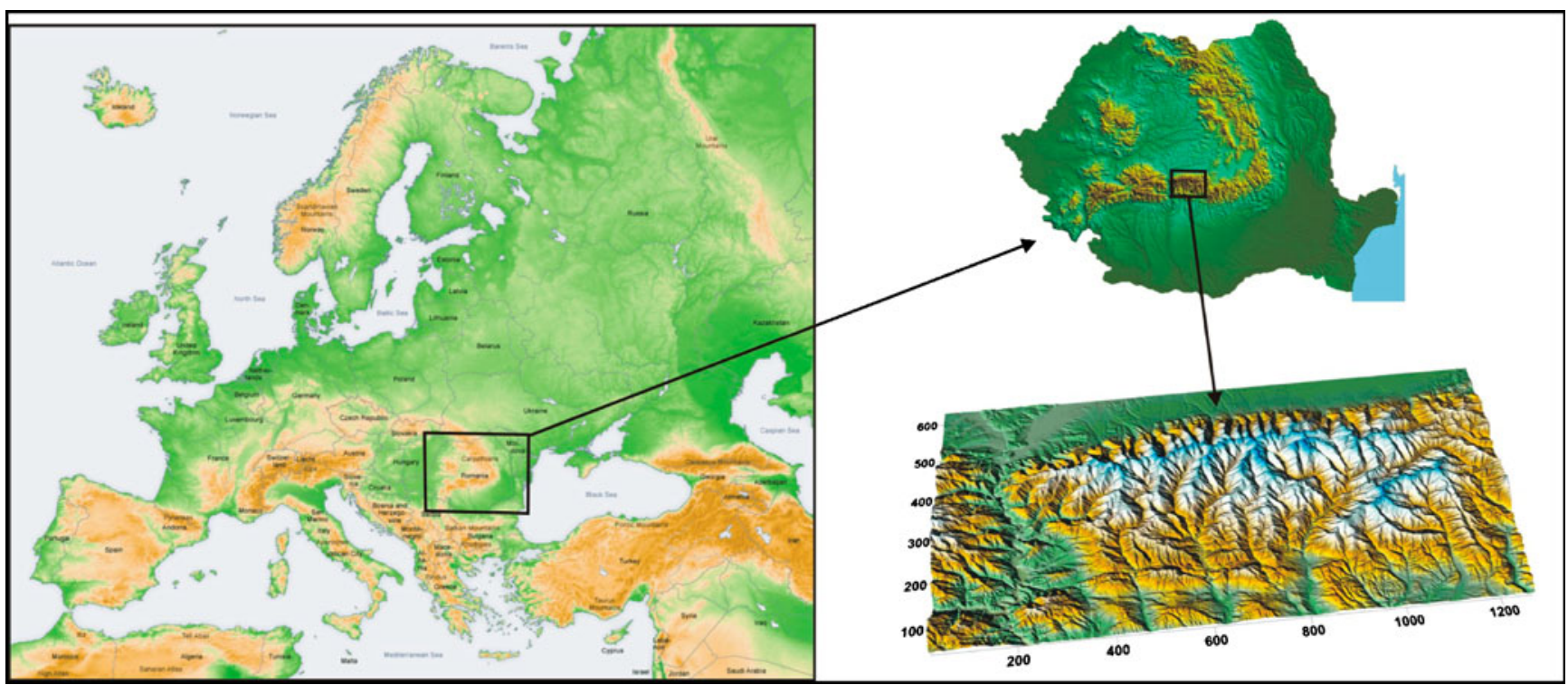

Figure 1. Geographical location of the study area.

narrow and deep saddles (small gates), pinnacles, ridges.

The analysed area is little present in the Romanian geographic literature. Thus, there are studies with a local character (Urdea 2000; Nedelea 2003, 2005), comparative studies (Mihai and Nedelea 1999), referring to very large areas (Bălteanu and Călin 1996) or to a single process avalanches (Voiculescu 2002). Most of the works belong to European alpine areas, referring either to the unfolding of some processes (Raczkowska 1997), to the evolution of the relief in periglacial climate (Chardon and Rovera 2002; Rovera 1990; Tenthorey 1987), or the relationship between processes and mountainous space organising (Chardon 1984). For the andine areas, the works of Francou (1984, 1988) are to be mentioned, for the Scandinavian Alps (Raczkowska 1990) and for the Tatra (Kotarba et al 1987; Kotarba and Pech 2002; Neboit-Guilhot et al 1990; Raczkowska 2004) where there are found the evolution of the relief in periglacial conditions, the denudation relief or the morphodynamic of alpine and subalpine slopes. The works dedicated to the Balkans are also important, strong resemblances with the analysed area being noticed (Grunewald et al 2006; Hughes 2007, 2009, 2010).

There are also numerous works with a theoretical character referring to avalanches (Gardner 1983; Keylock 1997; Ancey et al 2003; Johnson and Smith 2010), to the periglacial processes (Francou 1982) or to the risks from the high mountainous areas (Chardon 1990).

Although apparently they present a limited area (the Făgăraş Mountains), data and results obtained can be extrapolated to all Carpathian massifs with altitudes over $2000 \mathrm{~m}$, and also to other massifs which present the same geographic conditions. We chose to study this mountainous massif as it represents a model by the complexity of the processes and of the forms of relief. The main objectives of this work are: to establish the present or previous morphogenetic systems, to identify and map the resulting landforms, to establish some correlations between climatic conditions and the forms of relief resulting from it.

\section{Methodology}

In the field slope processes were mapped on topographic maps and aerial photographs. In the areas with bare rocks, the sensitive zones were studied based on maps and photographs. Every summer the effort consisted of identifying areas with debris accumulation, and the following activities were undertaken:

- assessment of deposit size;

- computation of rock volumes on several sites having an area of one square meter.

This study has used topographic maps of the region at 1:25,000 and 1:50,000 scales, aerial photographs at 1:50,000 scale, the Negoiu, Cumpana geological maps at 1:50,000 scale, as well as satellite imagery. As far as the climatic data are concerned, these have been provided by the nearest weather stations: Balea, Cumpana and Curtea de Arges.

\section{Results and discussion}

Depending on the factors that control it, relief shaping is accomplished through a range of 
closely associated mechanisms, which are grouped together in certain systems (Tricart and Cailleux 1967). The complex processes that contribute to relief degradation both by erosion and accumulation make up a morphogenetic system.

The contemporary relief shaping processes can be grouped into two categories depending on their intensity and duration:

- Periodical (seasonal) processes, which are represented by torrential streams, gully erosion, sheetwash, solifluctions, cryonival and gravitational processes, etc. Their action is more rapid and the effects are immediate and visible in morphology. These processes are controlled by the climate and are usually restricted to smaller areas.

- Permanent (fluvial) processes, exerted by the river network, which consist of erosion, transport and accumulation. These are more stable and occur at a slower pace, on the one hand because the topography of the Arges catchment develops on hard rocks and on the other hand because it is protected by a forest cover.

The permanent (fluvial) processes develop on a large area, roughly corresponding to the forest zone, which experiences a climate specific for middle-height mountains $(800-1800 \mathrm{~m})$. As far as the periodical (intermittent) processes are concerned, and especially the cryonival and gravitational ones, these are specific for the high ridges lying at elevations above $1800 \mathrm{~m}$, which experience the harsher climate of the high mountains covered by alpine grasslands (Bălteanu and Călin 1996).

Therefore, one can easily note that the areas in which shaping processes are active, mirror the vertical zonation of climate, which in its turn is controlled by terrain hypsometry. More than that, these areas make up two distinct zones, each of them displaying specific conditions of flow regime, soil and vegetation (Chardon 1984). The vertical climatic zones show two distinct shaping systems, namely the cryonival system and the fluvial system (figure 2).

In the next stage, we will present the most important modelling systems from the analysed area, systems that act both permanently and temporarily (periodical).

\subsection{The periodical processes}

The high mountain steps, generally lying above $1800 \mathrm{~m}$ form a typical morphosculptural area. This corresponds to the high ridges and summits, with their associated landforms: the large Borascu erosion platform (2000-2200 m) on the one hand, and the glacial cirques (Kotarba et al 1987), troughs and arêtes, lying around the main peaks
(Vanatoarea lui Buteanu, Lespezi, Capra, Fântăna, Vârtopel, Vârtopul, Buda, Râiosu, Muşeteica) (figure 2) or on the sides of the connecting ridges, on the other hand.

The present climate is milder than it used to be during the Pleistocene, when the glaciers occupied the valley headwaters (Urdea 2000). However, in comparison with the lower areas this climate is harsher and wetter, which hinders forest development. Here, the mean annual temperatures are usually around $0^{\circ} \mathrm{C}$, but on the high peaks, the values can drop to $-2^{\circ} \mathrm{C}$. In winter, the mean temperatures recorded in January range from $-7^{\circ} \mathrm{C}$ to $-9^{\circ} \mathrm{C}$, whereas in summer (July) the mean temperatures are less than $8^{\circ} \mathrm{C}$. The precipitation falling each year over the study area amounts to more than $1200 \mathrm{~mm}$, of which $50 \%$ is in the solid form. The number of frost days ranges from 250 to 265 days per year, depending on the altitude. The freeze-thaw action, which is extremely active during transition seasons, and the daily ranges of temperatures play an important part in terrain weathering through gelifraction processes. The snow cover, which persists longer (180-220 days per year) on the lee sides of the mountains, that is away from the dominant western, northwestern and southwestern winds, also contributes to the shaping of the land.

The present topography, made up of ridges, glacial cirques, flat or gently inclined surfaces and barren cliffs, encourages in its turn the action of cryonival, torrential and gravitational processes (Francou 1988).

A part of the rocks that underlie the Făgăraş Mts. (gneisses, paragneisses, micaschists and crystalline limestones) show many faults and cracks. In addition, they have been lifted to a nearly vertical position, which explains why gelifraction is extremely active. At the same time, gradational processes also affect the rocky surfaces lying on the highest peaks and ridges, in as much as soil blanket and vegetation cover are missing.

As a result of these conditions, the area is affected by denudation processes with a periodical character. The most important are the gelivation and nivation processes specific to the high mountain climate, which are associated in various degrees with additional processes, represented by gravitational displacements, sheet erosion, gullying and torrentiality (Mihai and Nedelea 1999).

The process is representative of the Făgăraş Mountains within the Romanian Carpathian ridges, but it is also present in the Balkans, where it plays an important role in modelling. In this respect, territories with a different unfolding from Bulgaria, Serbia, Montenegro and Albania impose on an area where the presence of some glaciers of small dimensions was reported (for example, the 


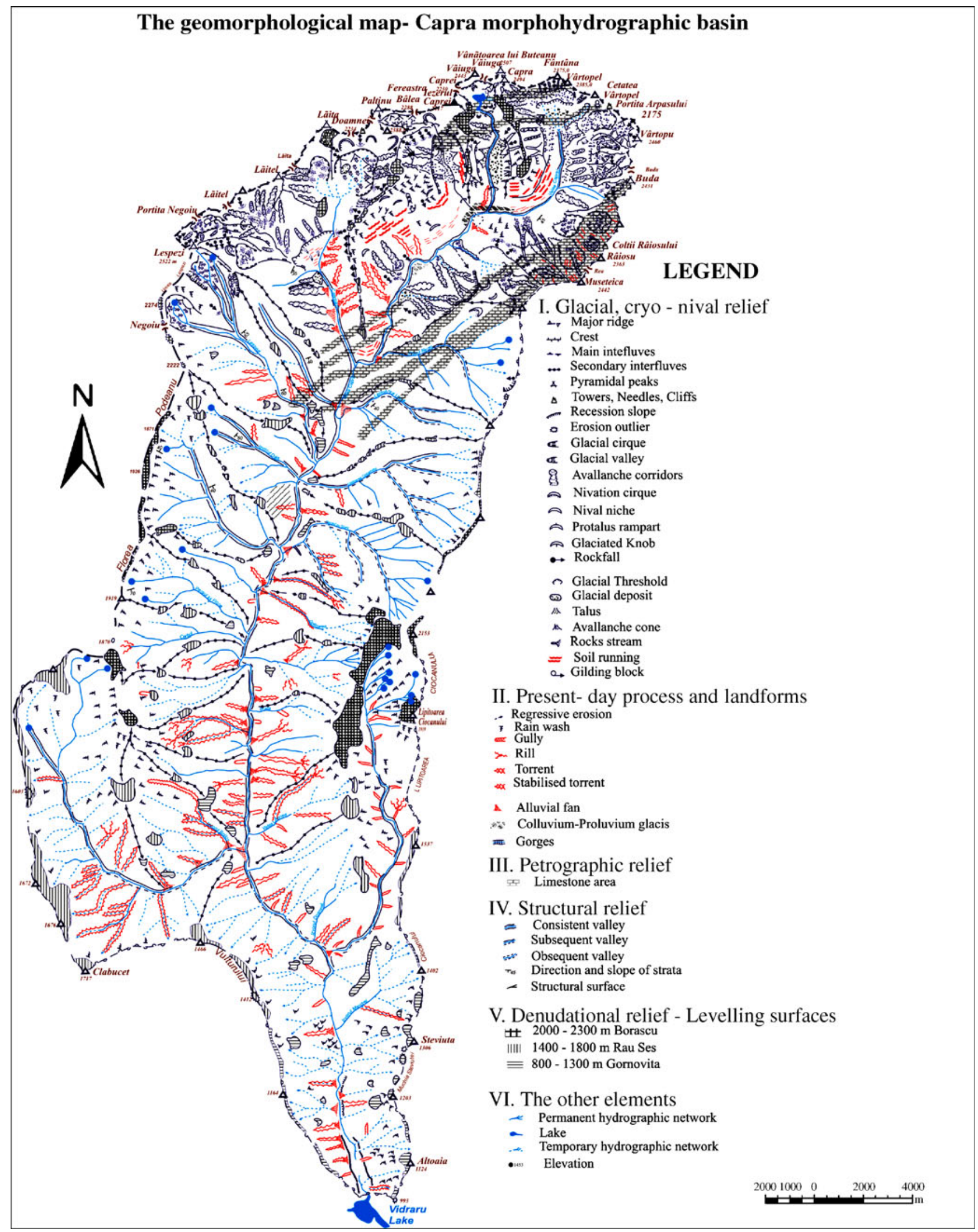

Figure 2. The Capra catchment - general geomorphological map. 


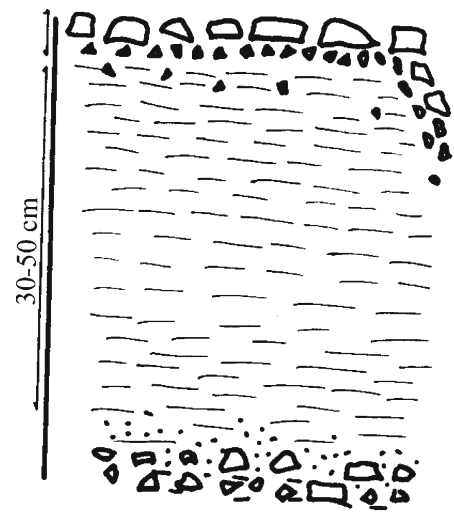

A.Stratified soil profile

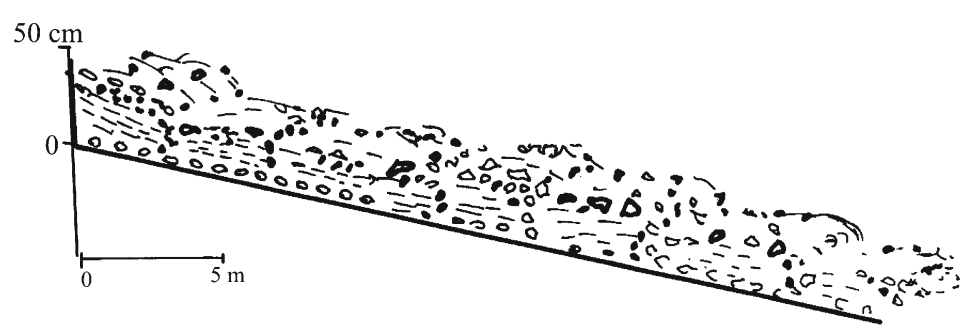

B. Stratified patterned grounds

Figure 3. Evidence of periglacial action on the Capra and Buda valleys.

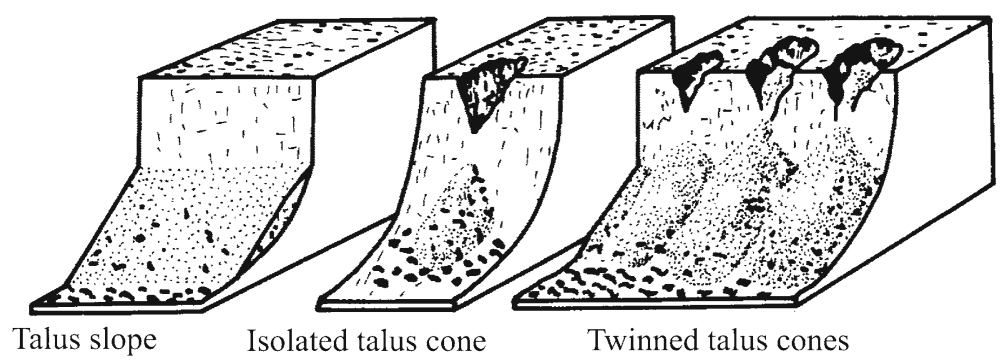

Figure 4. Types of screes in the Făgăraş Mountains.

four glaciers from the Prokletije Mountains from Albania, a glacier at the altitude of $2400-2500 \mathrm{~m}$ in Montenegro) (Grunewald et al 2006; Hughes 2007, 2009, 2010).

The gelivation processes encompass all the processes that are connected with freeze-thaw action and which become manifest through gelifraction, solifluction and regolith disturbance. Gelifraction pre-eminently affects the barren surfaces (the north-facing sides and the walls of the glacial cirques), whereas on the grassy slopes its force declines because of the protective soil and vegetation cover overlying the compact rock. Frost shattering prepares the ground for the gravitational and nival processes to which it is associated and contributes to the change of slope profiles through the piling up of detritus at the base of the slopes (figure 3) (Pech 1986; Nedelea 2005).

At present, gelivation processes affect especially the high ridges. During the Pleistocene, however, their realm was much more extensive, including also the lower parts of the Southern Carpathians (Urdea 2000). A result of this fact is the presence of the regolith with a thickness of 10-20 m (Nedelea 2005) which is now present on the cirques' slopes, covered by soil and forest vegetation.

The current gelifraction continues with a low intensity what Pleistocene gelivation and the former glaciers started a long time ago. Consequently, the interfluves are reduced to intersection ridges. The relief microforms resulting through gelivation can be grouped into two categories, as follows:

- Mechanical weathering landforms (residual landforms), represented by castellated relief (sharp serrated ridges, horns, needles, crags and faults), bare and highly degraded slopes, etc. On the knife-edge ridges separating the glacial cirques lying on the northern slopes, one can see a specific microrelief (nival niches, patterned grounds, stone rings) created by the gelivation processes that affect the gneisses, paragneisses and micaschists.

- Accumulation landforms, represented by talus slopes are spread on large areas. Depending on their position, one can distinguish eluvial screes (lying on the interfluves and inside the glacial cirques) and slope screes (figure 4).

As far as the disposition is concerned, one can note that on the gently inclined slopes and on the bottom of the glacial cirques the screes consist of large-size particles (boulders and slabs), which form rock fields that penetrate the upper stretch of the valleys. Elsewhere, the scree particles are 
smaller and consequently they roll down the torrential valleys that scar the rocky ridges generating rock streams. In the end, the detritic material piles up at the base of the slopes forming isolated or twinned talus cones, as it happens within most of the glacial cirques.

The active screes resulting from the weathering of slopes and glacial thresholds are largely spread within the glacial cirques and troughs. Usually, the present screes are underlain by a stabilized regolith that apparently came into being during the Pleistocene (Urdea 2000).

A particular category is represented by the reactivated screes, which have been exposed to the weathering agents after the sheetwash and gully erosion removed the soil cover of the stabilized screes. Below 1800-1900 m altitude, stabilized screes stretch out to the foot of the mountains giving evidence of the weathering processes that acted during the Pleistocene epoch (Urdea 2000).

The regolith (or the weathering crust) is an eluvial deposit found in an advanced state of crumbling and chemical weathering, which is the forerunner of soil cover. This deposit usually lies on the flat interfluves of the high ridges. Its formation is due to the gelivation processes that acted during the transition phase from the glacial climate to the present one, which continue even today, but with lower intensity.

The processes that disturb the initial structure of the regolith. The inner tensions caused by gelivation in the rock faults lead to the alteration of the structure of the finer eluvial and deluvial materials. These processes, sometimes associated with solifluctions, are responsible for the formation of patterned grounds, rock garlands and earth hummocks.

The rock garlands are nothing else but curved strips of scree, a few meters wide and tens of meters long. On the southern slopes of the Făgăraş Mts. and in some other parts of the mountain range, one can see several rows of rock garlands separated by nival depressions (figure 5).

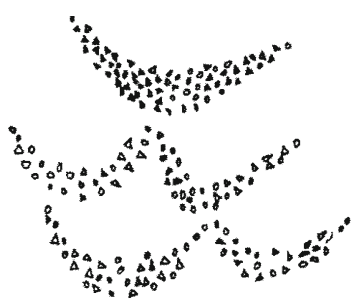

A. Top view

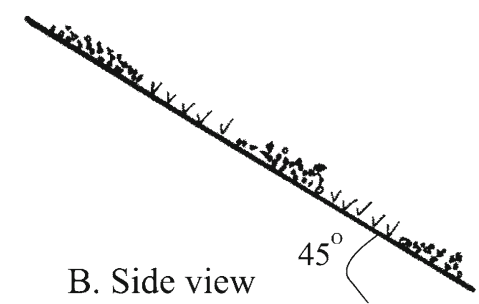

B. Side view
The earth hummocks usually occur on organic soils under waterlogging conditions. They can be seen on extensive areas on the alpine grasslands, as well as on the Borascu Platform, but they are also found at lower altitudes, below the tree line (the 'Molivis' peat bog, lying on the northern side of Mount Ghitu) (in south of the area) (figure 2).

In the study area, the solifluction processes are rather active during the thawing period, when the soil is imbued with water proceeding from spring rainfalls and snow melting. Consequently, the softened soil begins to slide down the gently inclined slopes on the still frozen layer lying beneath. The process repeats every year, giving birth to a microrelief represented by gelisolifluction benches and sliding rocks.

Nivation processes are encouraged by the long persistence of a snow layer (150-200 days per year), especially on the shadowed slopes, facing to the north. The snow plays a very important morphogenetic role for the upper zone of the Southern Carpathians, where, because of the cold climate, stream erosion is limited in time and intensity. The shaping action of snow becomes manifest both mechanically (pressures, erosion, avalanches) and chemically, under the influence of snow melting water (dissolution, oxidation). Nivation processes also operate on the lower ridges lying between 1500 and $1700 \mathrm{~m}$ altitude (Raczkowska 1990). Nivation has several ways of manifestation, as follows:

The settling and the slow nival erosion processes. The action exerted by the snow layer on the loose materials covering the flat interfluves and the slopes (slope deposits) has led to the enlargement of soil microdepressions and encouraged the formation of nival niches and cirques at the headwaters of the torrential streams. The resulting forms are represented by:

- nival microdepressions ('scochine'), which depending on the position and topography can be grouped as follows: plateau nival microdepressions (lying on the large ridges); ridge nival microdepressions, usually filled with water; slope nival microdepressions; and nival microdepressions lying within the glacial cirques and troughs, formed on the moraine deposits and on the talus slopes (the Paltinu, Capra, Museteica, Raiosu and Buda cirques - in north of the area) (figure 2).

- nival niches, found especially on the shadowed slopes of the glacial cirques and saddles (at the headwaters of the Fundul Caprei, Izvorul Podul Giurgiului, Izvorul Moldoveanu and Caltun valleys).

Figure 5. Rock garlands. 
- nivation cirques, formed by the pressure and slow erosion exerted by the snow layer in the catchment areas of some torrential streams (Nedelea 2005).

The avalanches are phenomena with rapid mechanical action and immediate destructive effects. They play a rather important part in the shaping of the slopes lying in the alpine and subalpine areas of the massifs, especially when these are steep and face to the west and southwest. Apart from their direct action of driving the detritic material down the slopes, avalanches open the way for other shaping agents that attack the bare surfaces (gelivation, surface erosion, torrential erosion).

Avalanche action repeated year-by-year leads in time to the enlargement of the shallow torrential valleys on which they occur and to the formation of some several meters wide avalanche chutes on the slopes (Voiculescu 2002). Subsequently, these continue to be shaped by snow and overland flow (Gardner 1983, Ancey et al 2003).

Here and there, one can see mantles of waste developing on amphibolites, micaschists and paragneisses, formed through the oxidation processes caused by the prolonged contact between the snow and rocks (Johnson and Smith 2010). The rolling of scree particles down the torrential valleys combined with their sliding in winter on the snow piled up at the base of the slopes generate specific accumulation microforms known as protalus ramparts (nivation moraines). They are particularly obvious within the Capra, Buda and Podul Giurgiului cirques, where they lie at the base of the cliffs affected by intense degradation processes (Nedelea 2003).

Similar processes are also found in Albania, Bulgaria or Montenegro in the proximity of the perimeters occupied by glaciers, many times contributing to their filling (Gardner 1983), a fact which happened in the Făgăraş Mountains, too, during the last glaciation.

Torrential streams act with conspicuous effectiveness on alpine grasslands topography (Rovera 1990). The abundant precipitation of May and June and the slow melting of the snow accumulated on the torrential headwater catchments encourage soil erosion, torrential processes and the removal of eluvial-deluvial particles (figure 6).

Torrential streams cut their channels not only in the stabilized screes that cover the gentler slopes but also in the parent rock. Their headwater erosion affects larger and larger grassy areas, from which they detach rocks that roll down the stream channels.

The high gradients and the low resistance to erosion of deluvial deposits allow the formation and rapid development of rills, furrows and gullies, which deepen into the parent rock and grow larger by lateral cutting. Torrential erosion processes are more active in the catchment areas lying at the valley headwaters.

On the cliffs of the glacial cirques, torrential erosion and the rock streams give birth to talus cones (Urdea 2000). These are generally stabilized, especially within the cirques lying on the southern and eastern slopes, where soil-forming processes are more advanced. By contrast, in the cirques lying on the northern side talus cones are generally loose.

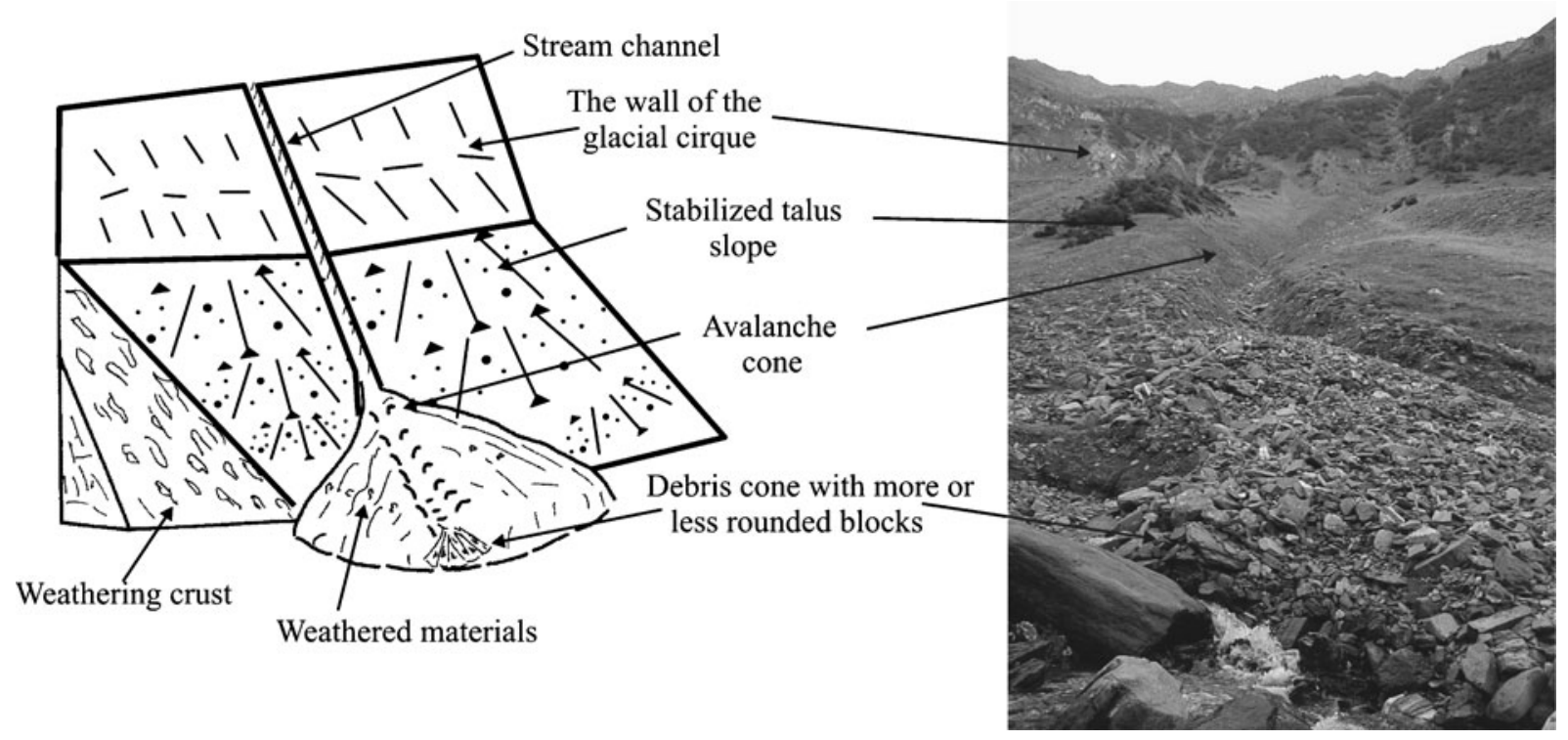

Figure 6. The model of a torrential stream on the Buda valley. 
Pluvial erosion plays an important role in the modelling of the slopes in the alpine and subalpine area. The high amounts of precipitation falling to the ground contribute to soil erosion and relief shaping by sheetwash and rill erosion. Their effects are obvious on the areas devoid of soil and herbaceous vegetation. Sometimes, the sheetwash also affects the eluvial and deluvial deposits subjected to gelivation processes, especially when the soil blanket is missing. In many cases, these processes are triggered by overgrazing, by pastures expansion to the detriment of juniper trees, or by the intense circulation of sheep and cattle.

Sheetwash and rill erosion prepare the ground for torrential erosion and contribute to the development of torrential streams. The fine deluvial material deposited on the slopes contribute to scree stabilization and soil consolidation (Neboit-Guilhot et al 1990).

\subsection{The permanent processes}

Below the upper tree line, which lies at about $1800 \mathrm{~m}$ altitude, fluvial shaping processes are more intense on the deforested slopes. This area experiences a more moderate regime of air temperature, characterized by mean annual ranges of $18^{\circ}-$ $20^{\circ} \mathrm{C}$ and lower daily ranges in comparison with the hilly and plain regions. The western slopes are wetter and colder, whereas the eastern ones are drier. At the upper part of the slopes, precipitation may reach or even exceed $1200 \mathrm{~mm}$ per year. On the shadowed, north-facing slopes, soil and air temperature regime is moderate.
Triggered by the Pliocene-Quaternary movements, the fluvial erosion processes are mainly represented by deep erosion, which is encouraged by the steepness of the river longitudinal profiles (average $10^{\circ}-15^{\circ}$ ). The erosion is more active within the big and well-developed valleys (Arges, Capra, Buda, Cumpana), but also along the streams originating from the glacial cirques, richly fed by numerous springs (Nedelea 2005). Erosion processes are extremely active in spring-time, during the heavy rainfalls and after massive snow melting. On the alpine grasslands, fluvial erosion is weak most of the year, except during the spring. It especially affects the moraine deposits and the glacial thresholds in which it carves connection gorges that mitigate the breaks of slope.

Like the erosion, the transport processes are more active during the spring rainfalls, when rivers have high discharges and can move away the coarse materials. As for the accumulation processes, these are generally weaker and occur at stream junctions and at the mouth of the tributaries, generating alluvial fans that close the trunk river floodplains.

The analysis of present day relief shaping processes reveals that these are grouped into two main vertical zones, depending on the climatic conditions. The first one is the zone of cryonival processes or the cryonival zone, which develops above $1800 \mathrm{~m}$ altitude in the realm of alpine grasslands. As mentioned earlier, the processes that prevail here are gelivation, nivation, gravitational displacements and torrentiality. Because the soils and vegetation are scarce, all these processes are

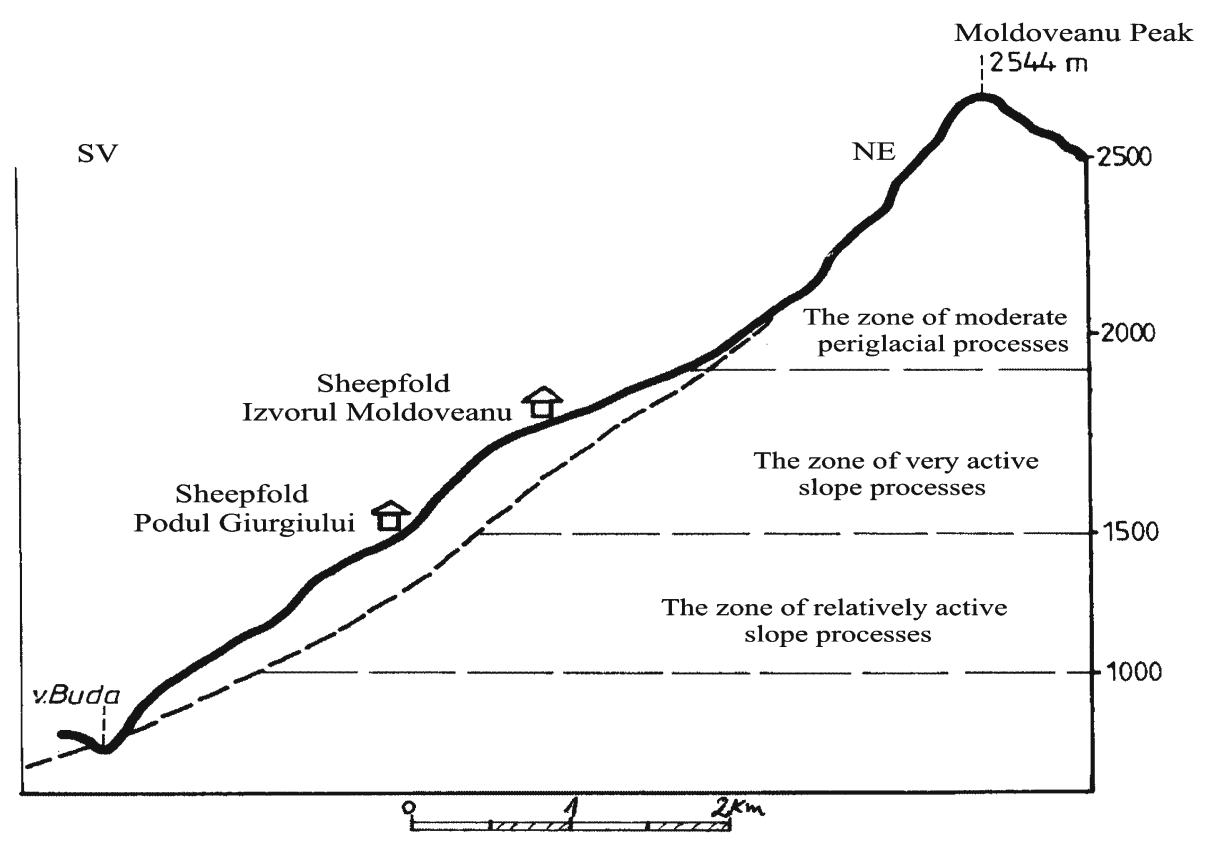

Figure 7. The vertical zonation of the prevailing morphodynamic processes in the upper section of the Buda catchment. 
extremely aggressive. The second is the zone of fluvial processes, which overlaps the forest zone lying below $1800 \mathrm{~m}$ altitude, where fluvial erosion and accumulation are typical. Here, cryonival processes play a secondary part in the shaping of the land (figure 7).

\section{Conclusions}

One can note that current geomorphological processes develop according to the vertical zonation law. This explains the vertical distribution of the morphogenetic processes, as well as of the other elements of the physiographic complex that control them.

Cryonival processes continue on a smaller scale, the periglacial processes that used to operate during the Pleistocene on a more extensive area (Tenthorey 1987; Urdea 2000).

In those times, the upper zone of the Făgăraş Mts. was covered by permanent snow and displayed many cirque and valley glaciers. Likewise, the lower areas represented an immediate periglacial zone, followed at the foot of the mountains by a more remote periglacial area, where seemingly the fluvioglacial accumulation was very active.

These processes are less developed than in other areas from the Balkans and less present than about 150 years ago, during the Little Ice Age. For example, elsewhere in the western Balkans, snow and ice was much more extensive at this time. Thus, the presence of some very extended glacial cirques and icefails in the massif Durmitor from Montenegro and the lichenometric analyses lead to the existence of eight glaciers present in this area in the 19th century, their peak coinciding with Little Age (Hughes 2010).

During the Holocene, as the glaciers shrank, periglacial processes gradually migrated towards the ridges and the glacial cirques, thereby affecting only the alpine grasslands and especially their upper part (Urdea 2000). At present, this area is the realm of cryonival and fluvial shaping. The former periglacial area has now been taken over by the fluvial shaping system, which operates on a more extensive area, including the forest vertical zones. The way the contemporary geomorphological processes manifest themselves mirrors the current dynamics of topography, which is rather active, in as much as it is impelled by the PlioceneQuaternary tectonic movements.

At the same time, it should be emphasized that the effects of the analyzed processes are not restricted only to relief shaping, but they also impact the other components of the natural setting as well. Thus, one can see that in the alpine grasslands zone, in particular, the contemporary geomorphological processes alter the properties of various elements of the mineral substratum encouraging the formation of soil or, on the contrary, contributing to its degradation. The systematic study of present day relief shaping processes in the upper Arges catchment also raises multiple practical problems dealing with the improvement and the rational use of the lands, from the perspective of the complex capitalization of the economic potential of the mountain massif (pastoral economy, wood harvesting, transportation routes, tourist infrastructures).

\section{Acknowledgements}

The authors would like to thank all those who supported the preparation and publication of this article, within the project: "Evaluation and Monitoring of Avalanche Risk in the Context of Mountain Environment Organising and Planning. Case Study - Făgăraş and Piatra Craiului Mountains". Project Manager - Alexandru Nedelea, financed by CNSIS, category IDEI/1934.

\section{References}

Ancey C, Meunier M and Richard D 2003 Inverse problem in avalanche dynamics models; Water Resour. Res. 39(4) 1099-1112.

Bălteanu D and Călin D 1996 L'etagement des processus geomorphologicues actuels dans les Carpates Méridionales; Geographical International Seminars, Inst. Geogr. Bucureşti 3 1-9.

Chardon M 1984 L'étagement des paysages et les processus géomorphologiques actuels dans les Alpes occidentales; Studia Geom. Carpatho-Balcanica 17 33-43.

Chardon M 1990 Quelques réflexions sur les catastrophes naturelles en montagne; Rev. Géogr. Alp. 1-3 193-213.

Chardon M and Rovera G 1992 Vitesse d'évolution des versants réglés en montagne alpine; Bulletin Association des Géographes Francais, pp. 246-249.

Francou B 1982 Chutes de pierres et éboulisation dans les parois de l'étage périglaciaire; Rev. Géogr. Alp. 70( 4) 279-300.

Francou B 1984 Données préliminaires pour l'étude des processus périglaciaires dans les hautes Andes du Pérou; Rev. de Géom. Dyn. 33(4) 113-126.

Francou B 1988 L'éboulisation en haute montagne - Andes et Alpes; Thèse de Doctorat, Départament de Géographie, Université de Paris VII, France.

Gardner J S 1983 Observation of erosion by wet snow avalanches, Mount Rae, Alberta; Canada, Arc. Alp. Res. 15(2) 271-274.

Grunewald K, Weber C, Scheithauer J and Haubold F 2006 Mikrogletscher im Piringebirge (Bulgarien); Zeitschrift für Gletscherkunde und Glazialmorphologie $\mathbf{3 9}$ 99-114.

Hughes P D 2007 Recent behaviour of the Debeli Namet glacier, Durmitor, Montenegro; Earth Surf. Proc. Land. 10 1593-1602. 
Hughes P D 2009 Twenty-first Century Glaciers in the Prokletije Mountains, Albania; Arctic, Antarctic and Alpine Research 41 455-459.

Hughes P D 2010 Little Ice Age glaciers in Balkans: Low altitude glaciation enabled by cooler temperatures and local topoclimatic controls; Earth Surf. Proc. Land. 35 229-241.

Johnson A L and Smith D J 2010 Geomorphology of snow avalanche impact landforms in the southern Canadian Cordillera; The Canadian Geographer 54(1) 87-103.

Keylock C 1997 Snow avalanches; Progress in Physical Geography 21(4) 481-500.

Kotarba A, Kaszowsky L and Krzemien K 1987 Highmountain denudational system of the Polish Tatra Mountains; Polish Acad. Sci., Geogr. Studies 3 31-48.

Kotarba A and Pech P 2002 The recent evolution of talus slopes in the high Tatra Mountains (with the Panszczyca Valley as example); Studia Geomorphologica CarpathoBalcanica XXXVI 69-76.

Mihai B and Nedelea A 1999 Câteva comparaţii geomorfologice între masivele înalte din Carpaţi. Studiu de caz: Munţii Făgăraş-Tatra Înaltă; Com. de Geografie III 159-167.

Neboit-Guilhot R, Valadas B and Lageat Y 1990 Dynamique rapide et modelé des versants supra-forestiers des hautes Tatra polonaises; Rev. Géogr. Alp. 1-3 259-280.

Nedelea A 2003 Dinamica versanţilor în sectorul superior al văii Buda (Munții Făgăraş); Com. de Geografie VII 33-40.

Nedelea A 2005 Procese periglaciare în sectorul montan al văii Argeşului; Com. de Geografie. IX 43-50.
Pech P 1986 La dynamique des versants dans l'Ossola (Italie du Nord, Alpes Centrales); Rev. de Géogr. Alp. 4 355-371.

Raczkowska Z 1990 Observations on nivation and its geomorphological effects in mountains at high latitude (with Mt. Njulla Massif in northern Sweden as example); Pirineos. 136 19-32.

Raczkowska Z 1997 Nivation and its geomorphic significance - examples from the Polish High Tatra and the OrtlesCevedale Massif, the Italian Alps; Studia Geomorphologica Carpatho-Balcanica XXXI 175-192.

Raczkowska Z 2004 Considerations on periglacial landforms and slope morphodynamic in periglacial zone of Tatra Mountains; Analele Universitătii de Vest din TimişoaraGeografie. XIV 35-50.

Rovera G 1990 Géomorphologie dynamique des versants en Moyenne Tarentaise (Savoie); Thèse $\mathrm{d}^{\prime}$ Univ. J. Fourier, Grenoble, France.

Tenthorey G 1987 Etude sur le périglaciaire dans les Alpes penniques; Cahiers de l'Institut de Géographie de Fribourg 5 151-159.

Tricart J and Cailleux A 1967 Le modelé des régions périglaciaires; Sedes, Paris, 512p.

Urdea P 1988 Consideraţii asupra gheţarilor de pietre din Munţii Retezat; $S C G G G$ - seria Geografie XXXV 85-90.

Urdea P 2000 Munţi Retezat. Studiu geomorfologic, Edit. Acad. Rom., Bucureşti, 272p.

Voiculescu M 2002 Fenomene geografice de risc în Masivul Făgăraş. Edit. Brumar, Timişoara, 231p. 